\title{
9 Countering radicalisation in Norwegian terrorism policy
}

\author{
A welfare state approach to \\ societal security
}

Sissel H. Jore

\section{Introduction}

During the last decade, there has been a growing focus in most Western countries on preventing individuals from becoming radicalised. The militarised response of the "Global War on Terrorism" doctrine has not been regarded as sufficient to meet the threat of so-called home-grown terrorism, and subsequently current counterterrorism policies focus on preventing terrorism through understanding the underlying causes of terrorism (Sageman, 2014). Central to this new doctrine is the belief that countering terrorism requires contextualised and locally based efforts to identify individuals capable of turning towards terrorism in a heterogeneous society (Borum, 2011). The underlying notion is that terrorism is a ubiquitous and permanent condition of modern society and that terrorism can be prevented by focusing on "radicalisation", which is understood as a way to classify, understand, and prevent trajectories towards terrorism (Awan et al., 2011; Crone, 2016; Horgan 2008; Sedgwick, 2010). Accordingly, to counter terrorism through the lens of radicalisation is nowadays regarded as a necessary element of an effective and comprehensive counterterrorism strategy. As a result, most Western countries, including the Nordic countries, have during the last decade published anti-radicalisation strategies (Aly, 2013, Sivenbring and Malmros, 2019).

Also in the last decade, terrorist attacks in the Nordic countries have occurred that have illustrated that there are radicalised individuals also in the Nordic countries who pose a danger to society. Examples of such events are the terrorist attacks in Norway in 2011 by Anders Behring Breivik, the Copenhagen terrorist attack in 2015 by Omar Abdel Hamid El-Hussein, the stabbing attack in Turku in 2017 by Abderrahman Bouanane, the truck attack in Stockholm in 2017 by Rakhmat Akilov, and the mosque shooting attack in Bærum by Philip Manshaus in 2019 (Sivenbring and Malmros, 2019). During this time period, all the Nordic countries have published a considerable number of counter-radicalisation strategies, especially focusing on preventing terrorism at the local level where municipalities, schools, and social workers are now responsible for detecting, reporting, and preventing radical individuals (Mattsson, 2019; Sjøen and Jore, 2019). 
In all the Nordic countries, counter-radicalisation nowadays is described as a multilevel, multiagency approach where civil society plays a central role (Sivenbring and Malmros, 2019). The increased focus on radicalisation and the associated devolution of counterterrorism responsibility to the local level is a trend the Nordic countries share with most countries worldwide. However, even though an increasing number of threats against Nordic security is global in character, global threats such as terrorism always have local manifestations. The threat picture any society faces may be globally oriented, but a shared global perception of terrorism is unlikely (Burgess and Jore, 2008). Thus, how a country perceives the threat of terrorism and how it should be prevented are determined by local properties rather than global ones. Particular cultural traditions, a distinct historical background, and a concrete geographical setting are factors that influence threat perception and accompanying countermeasures. Consequently, policy responses to terrorism are never neutral - they are always culturally, historically and socially contingent. Moreover, such policy responses also have consequences for how security is perceived, organised, and acted upon in a specific country.

This chapter approaches the discourses and practices of "societal security" through the case of Norwegian counterterrorism policy and investigates the radicalisation approach that currently dominates the Norwegian approach to terrorism. Counterterrorism serves as an example of how societal security is perceived, carried out, and organised in Norway. The radicalisation approach is investigated by studying 4 national guidelines and 36 municipalities' guidelines on how to prevent radicalisation. The aim is to examine the assumptions about terrorism in the radicalisation approach and explore whether this approach is similar or different from previous Norwegian approaches on terrorism prevention. We conclude that although the Norwegian radicalisation approach follows a historical trend of seeing terrorism as an extreme form of communication utilised by marginalised groups, the current approach differs from previous terrorism approaches by focusing on individuals as the locus of change, and where social-psychological factors are considered causes of terrorism. This way of viewing terrorism decontextualises and depoliticises terrorism by downplaying political and international factors. The radicalisation approach represents a radical change in the Norwegian terrorism approach that justifies efforts associated with the Norwegian welfare state as counterterrorism means and legitimises the use of counterterrorism measures that formerly have been seen as threats to civil liberties. As a result, the Norwegian radicalisation approach legitimises a decentralised form of security where local actors and individuals become a form of first line defence.

\section{The Norwegian approach to terrorism and counterterrorism in a historical perspective}

In the Nordic countries and elsewhere in the Western world, security has come to be organised around a rather holistic conceptualisation of what 
composes a threat as well as the range of responsibilities required to address them (Larsson and Rhinard, this volume). Over the past two decades, terrorism has increasingly been portrayed as a threat to Norwegian peace and security. Although terrorism and radicalisation nowadays are phenomena that feature strongly in policy documents and the media, this has not always been the case in Norway. What constitutes the threat of terrorism, its magnitude, and the legitimate ways to counter it have changed drastically over the last three decades (Jore, 2012, 2016; Larsen, 2018).

In the $1990 \mathrm{~s}$, the threat of terrorism was predominantly seen as something that happened in other countries. Consequently, most terrorist threats against Norway were seen in relation to high-level visits, such as threats to controversial political actors coming to Norway to receive the Nobel Peace Prize. The risk of terrorism was assessed as low, and there was a general belief in Norwegian policy discourses that there were characteristics of Norwegian society that made Norway a low-risk society. For instance, Norway was described in the 1990s as geographically remote, homogeneous, inclusive, and transparent: all factors that appeared to make Norway less of a target for terrorism (Ministry of Justice 1993; Jore, 2012). In that era, counterterrorism measures were regarded as a controversial and unnecessary element of a free, open, and democratic society. In accordance with this view, Norway refused to implement counterterrorism measures, such as specific legislation against terrorism, that might be seen as a threat to civil liberties. At the time, terrorism was not a major concern and the responsible parties involved in terrorism security were national actors: for instance, the defence establishment and the police (Jore and Njå, 2008). Thus, security practices associated with terrorism were considered a centralised responsibility.

The terrorist attacks in the US on 11 September $2001(9 / 11)$ put terrorism on top of the political agenda in most Western countries. This was also the case in Norway. Terrorism after $9 / 11$ was framed as a catastrophic risk that threatened democracy, modernity, national security, and critical infrastructures. Therefore, the whole of society needed to be protected, in line with broader societal security discourses outlined in this book. From this time, counterterrorism measures went from being presented as threats against civil liberties to a necessity (Jore and Njå, 2009). In Norway, counterterrorism measures were presented as a trade-off between security and liberty; in order to achieve security, some civil liberties had to be sacrificed. Thus, it was essential to find the right balance between previous "naiveté" and a turn towards a totalitarian state (Jore, 2012).

After the terrorist attack in Norway on 22 July 2011, debates on countermeasures re-intensified and numerous measures were implemented, on multiple scales, to prevent future attacks (Kolås, 2017). Counterterrorism went from being a national and centralised responsibility to becoming a multilevel and multiagency responsibility where the local level and civil society played an important role. It was during this time, in fact, that the concept of radicalisation appeared in Norwegian policies. The outpouring 
of foreign fighters from Norway and attacks from the Islamic State in Nordic and European cities raised concern that these actors could also target Norway. This further intensified the focus on radicalisation in Norwegian policy documents, but this approach to terrorism also carried with it a new conceptualisation of what terrorism is and how it should be prevented.

In Norway, the dominate conceptualisation of terrorism has for many decades been to regard it as a form of political violence. Terrorism was seen as an extreme form of political communication fighting for a political purpose (Jore, 2012). Thus, in Norwegian official discourses, terrorists have been described as rational actors that might be fighting for a legitimate cause. For instance, one official text argued that:

...several groups and organizations are fighting for morally good values such as freedom and political independence, but in this fight use acts of terrorism as political means

(Ministry of Justice, 1993, p. 12).

This was the prevailing view of terrorism in the Norwegian official communication over several decades. Although other discourses on terrorism coexisted (Jore, 2012), the dominant substantiation of terrorism in the official discourse was to see terrorism as an extreme form of political violence that should be fought by targeting root causes by improving social justice and dialogue. Even though Norway participated with military forces in the US-led Global War on Terrorism, military activities from a Norwegian perspective were most often framed as peacebuilding and peacekeeping operations.

The transformation from hard counterterrorism measures, such as the militarised participation in the Global War on Terrorism doctrine, towards newfound attention to understanding the underlying causes of terrorism is, at first glance, in line with the Norwegian conceptualisation of terrorism and what is considered legitimate ways to counter terrorism. However, the shift of terrorism responsibility from a centralised responsibility to a decentralised and local multiagency focus also entailed a shift in who is responsible for securing society. Thus, the radicalisation approach brought about a change in how security in Norway was perceived, executed, and provided in the Norwegian society.

\section{Theoretical and methodological approach}

The focus on preventing terrorism through the lens of radicalisation is a European trend that reached the Nordic countries in the first part of the current decade. Denmark was the first Nordic country to publish an Action Plan against extremism in 2009 (Sivenbring and Malmros, 2019). At the time, several terrorist plots had been revealed or terrorist attacks had taken place in the Nordic countries. Additionally, the concern about so-called 
foreign fighters was rising in the Nordic countries. During that time, all the Nordic countries published counter-radicalisation strategies that portrayed terrorism as a major threat to Nordic security (Ibid). Norwegian authorities published an Action Plan for how to prevent radicalisation and violent extremism in 2010. Hence, the Action Plan against radicalisation in 2014 was a revision of an already existing strategy. In the years following the revised Action Plan, numerous guidelines and action plans were published in different sectors, especially on the municipality level.

The material analysed in this chapter consists of Norway's 4 radicalisation actions plans and guidelines published at the national level, and 36 action plans and guidelines published at the municipality level (for a complete list, see the annexes to this chapter). We investigate the assumptions behind the threat of terrorism, the assumed causes of terrorism, and the views on legitimate counterterrorism measures. Our postulate is that the reorganisation of counterterrorism responsibility in Norway is contingent on how the terrorism threat is perceived and the associated understanding of what measures are regarded appropriate and legitimate. The starting point is that terrorism is not a neutral word used to refer to an independent, objective, ontological phenomenon. The concept of terrorism functions as a subjective, normative frame that shapes and constructs how individuals and society view a threat and the legitimacy of such actors and associated counter measures (Jackson et al., 2011). Thus, the Norwegian conceptualisation of terrorism as a threat is contingent on historical, cultural, and political framings. Consequently, the terrorism concept cannot be separated from its broader context. Different conceptualisations of terrorism influence what society perceives as effective ways to counter terrorism (Crelinsten, 2009; Jackson et al., 2011), and, as a result, the perception and organisation of terrorism lays the premises for different notions and practices of security.

\section{The radicalisation approach}

The radicalisation concept did not feature strongly in Norwegian terrorism approaches before the publication of the Action Plan to prevent radicalisation and violent extremism in 2010. In fact, it was a concept that was rarely found in official documents previously. Thus, to publish an Action Plan to prevent radicalisation and violent extremism that almost exclusively focused on the prevention of radicalisation marked a change in Norwegian counterterrorism policies when it came to what terrorism was, how terrorism should be prevented, and what were considered effective and legitimate ways to counter the threat.

\section{Assumptions of terrorism as a threat}

The Norwegian Action Plan to prevent radicalisation and violent extremism published in 2010 described the Norwegian threat picture as similar to that 
of other European and Nordic countries. The security situation for Norway was described as:

.... a transition to a terror threat picture more like the one we see in countries where terror attacks have been or have been attempted to be carried out.

(Ministry of Justice and Public Security, 2010, p. 5)

The argument was that because of the increased terrorism threat, Norway had to take:

.... a precautionary approach. Providing protection is also about prevention, both here in Norway and internationally.

(Ministry of Justice and Public Security, 2010, p. 5)

What the Norwegian 2010 Action Plan referred to when talking about precautionary prevention was to prevent terrorism through the lens of radicalisation. Thus, to protect society it was deemed necessary to focus on the processes that led to terrorism. This process was one in which groups or individuals developed attitudes that supported the use of political violence as a means. The 2014 Action Plan against Radicalisation described radicalisation as:

.... a process whereby a person increasingly accepts the use of violence to achieve political, ideological or religious goals.

(Ministry of Justice and Public Security, 2014 p. 7)

The process of radicalisation that could result in violent extremism was characterised as:

.... a process whereby a person or group increasingly condones the use of violence as a means to reach political, ideological or religious goals, and whereby violent extremism may be a result.

(Ministry of Justice and Public Security, 2015, p. 13)

Accordingly, radicalisation was considered a process of attitude change, whereby the most extreme consequence of the radicalisation process was terrorism. This process was described as a sequential and linear trajectory in which violent behaviour followed a radical attitude change, whereby a person became more and more likely to utilise violence as a political means. This process was described in multiple documents as the "Radicalisation Tunnel". The policy goal was to prevent a person from entering into this process or stopping a person already on this pathway. The assumption was that if there is a process that leads to terrorism, there is also a way to stop or reverse this process by removing the intent to commit an act of terrorism. 
Thus, counterterrorism policy had become a matter of preventing certain attitudes or changing unwanted attitudes. The novelty of this framing of terrorism was that terrorism was now directly connected to a person's personal attitude. Previously, official documents had highlighted the importance of not criminalising attitudes, claiming that terrorists could just as well be fighting for a legitimate political issue (Ministry of Justice, 1993, p. 12). Thus, the idea that terrorists also could be seen as freedom fighters was no longer an element in the authorities' description of the phenomenon of terrorism. In the radicalisation approach, terrorism was only portrayed as negative - an act of fighting illegitimate political goals with illegitimate political means because these individuals had developed the "wrong" set of attitudes. The broader consequence of this was that security now had been directly connected to having the "right" kinds of attitudes.

\section{Perspectives on the cause of terrorism: individual vulnerability}

Preventing terrorism by targeting root causes has been an important element in the Norwegian understanding of terrorism over several decades (Jore, 2012). Up to the 2010s, the root causes of terrorism were primarily ascribed to political injustice. Terrorists were portrayed as rational actors fighting for a political agenda. Thus, root cases were traditionally understood as political injustice, poverty, lack of education, and lack of democracy.

The focus on root causes is still present in the radicalisation approach. However, since the radicalisation approach has a domestic perspective, root causes of terrorism are now translated into the Norwegian context. While root causes of terrorism historically were limited to political factors on the international and national level of other states, root causes are in the national and municipalities' action plans and guidelines attributed to aspects of the individual and to his or her living conditions in the local community not to broader characteristics of Norwegian society or politics.

The root causes of terrorism, in these texts, are thus described at the individual level, where individuals have some sort of vulnerability that make them prone to adopting extreme attitudes. Lillesand Municipality's Action Plan against radicalisation (2016, p. 10), for example, claims that four motivators play a role in the radicalisation process. First, extremists search for belonging and security. Extremists are driven by a desire for affiliation, friendship, and protection. Second, extremists are motivated by idealism and the sense of injustice. Extremists are driven by political and ideological goals, and get involved because of the suffering of others. Third, social frustration is also a motivating factor; extremists often have a wounded past, and may have experienced violence, discrimination, and substance abuse. Lastly, the quest for excitement or meaning in life is also a motivating factor; extremists are seen as driven by fantasies of being a hero who fights violently for "good" against "evil". The majority of the motivating factors mentioned are factors attributed to the individual level. Although the political aspect 
Table 9.1 Protective factors and risk factors on the individual level ${ }^{2}$

\begin{tabular}{|c|c|}
\hline Protective factors & Risk factors \\
\hline $\begin{array}{l}\text { - Reflective youth } \\
\text { - } \text { Hood school situation } \\
\text { - } \text { Copies or sports } \\
\text { - } \text { Robust } \\
\text { - } \text { Experience of meaning } \\
\text { - } \text { Quality of life } \\
\text { - Good health }\end{array}$ & $\begin{array}{l}\text { - Marginalised/discriminated } \\
\text { - Lack of belonging/seeking belonging } \\
\text { - School-related issues } \\
\text { - } \text { Psychological problems } \\
\text { - } \text { Lack of knowledge } \\
\text { - Seeking answers } \\
\text { - Individual vulnerability } \\
\text { - Consider themselves as victims } \\
\text { - Missing self-control/impulsive }\end{array}$ \\
\hline
\end{tabular}

of terrorism is mentioned, most of the issues considered to lead to terrorism are not described as political but as individual psychological and socioeconomic factors.

The national and local action plans against radicalisation describe socalled risk factors and protective factors for potential radicalised individuals. According to Tromsø Municipality (2018, p. 10), for instance, a risk factor may be defined as "any factor in the individual or in the environment that can be associated with increased likelihood of negative psychosocial development in the future". A protective factor is "any factor in the individual or in the environment that can be associated with a reduced likelihood of future negative psychosocial development". Consequently, protective and risk factors are connected to an individual's psychosocial development.

According to Lillesand Municipality (2016), protective factors and risk factors on the individual level are numerous, as outlined in Table 9.1.

Although official documents acknowledge that radicalisation is multicausal and complex, it is obvious that these documents highlight individual vulnerabilities caused by psychological and social-economic factors when explaining causes of terrorism. The assumption about the causes of terrorism is that terrorism derives from a form of individual vulnerability that makes a person prone to adopt extreme attitudes. These vulnerability factors are often attributed to aspects of the local environment that influence an individual's upbringing in a negative way. These descriptions of risk factors describe characteristics common in adolescence, and, consequently, all forms of mental health issues or negative psychosocial development can be interpreted as signs of radicalisation. Thus, vulnerability to radicalisation is described as similar to risk factors for young people in general. Roger Berg of the Norwegian Security Police, citied in a municipal report, argues that:

There are many and complex reasons why young people enter into a process where they gradually approach violent extremism, but often this is related to mental vulnerability, identity conflicts and conspiracy theories. 
It is apparent that the vulnerability approach permeates policies in Norway as shown in this statement. In fact, radicalisation is described as a random process caused by vulnerability:

Whether a person ends up having drug problems, being a criminal, or a violent extremist is a random process, depending on what problem "reaches" the person first. The commonality between all these issues is being vulnerable.

(Ministry of Justice and Public Security 2010, 8)

The focus on individual factors is perhaps best illustrated by the fact that many of the official documents reviewed here include lists of "Possible signs of concern" as exemplified in Table 9.2.

In the official documents published in recent years, there is one risk factor that receives particular attention: "outsiderness". The National Emergency Preparedness Council $(2018$, p. 2) defines outsiderness as a term used in everyday speech to denote inadequate social affiliation with the wider community. The term describes a situation in which individuals or groups of

Table 9.2 Possible signs of concern ${ }^{3}$

Statements/messages

- Intolerance for others' points of view

- Hostility to perceived enemies - us and them

- Conspiracy theories

- Hate rhetoric

- Sympathy for absolute solutions, such as abolition of democracy

- Legitimising violence

- Threats of violence in order to achieve political goals

Interests/appearance/use of symbols

- Providing and searching for extremist material on the Internet

- Changes appearance, style of clothing, etc.

- Uses symbols linked to extremist ideals and organisations

- Quits school or stops taking part in recreational activities, etc.

Activities

- Concerned with extremism on the Internet and in social media

- Takes part in demonstrations or in violent clashes with other groups

- Uses threats and violence as a result of extremism

- Hate crime

- Travel activities that may result in increased radicalisation and contact with extremists

Friends and social networks

- Changes network and social circle

- Associates with persons and groups that are known for violent extremism

- Associates with groups where threats, violence, or other criminal activities are practised

- Member of extremist groups, networks, and organisations 
people do not feel included in society because of bullying, marginalisation, or lack of linguistic or cultural affiliation. As such, to build an inclusive and just society where everyone has the same opportunities to education, work, health, and economic security has now become a part of counterterrorism policy. Consequently, measures associated with the provision of the Norwegian welfare state have become the means to counter terrorism. Moreover, since terrorism is predominantly attributed to the individual level, political factors or factors at the macro level are not considered important explanations of why people become terrorists. Consequently, the emphasis on radicalisation as an individual process de-emphasises broader social and political circumstances as explanatory factors. By focusing on individual factors, the political aspect of terrorism is downplayed in the radicalisation approach and security is conceived as building robust individuals using the traditional means of the Norwegian welfare state.

\section{Assumption about legitimate counterterrorism measures}

Since the Norwegian action plans against radicalisation describe the causes of radicalisation as individuals' vulnerability, the measures seen as legitimate are counterterrorism measures that aim to create safe and inclusive local environments for young people. The aim is to work with vulnerable individuals to develop a form of psychological robustness that makes potential terrorists refrain from radicalised ideas. The underlying assumption here is that terrorism can be prevented by developing some form of psychological capacity and critical reflection skills in individuals that prevent them from being drawn towards violent extremist ideologies or groups. Consequently, in the radicalisation approach, the ability to refrain from extreme ideas becomes a characteristic that can be learned and internalised. The main idea is that individuals should share the same political attitudes as the mainstream community. According to the underlying assumption, this should be achieved by living in harmonious local communities.

This notion of terrorism is grounded in the idea of terrorism as a product of social, economic, and political inequalities, and that alienated and marginalised individuals are more likely to engage with radical groups when they are isolated from the broader community or suffering mentally. Thus, social factors at the community level are aspects that help to prevent terrorism. Consequently, the official documents emphasise the importance of creating a safe and inclusive society for every individual as a way to prevent terrorism. Thus, avoiding outsiderness and providing young people with an inclusive socially and economically favourable local environment is seen as a counterterrorism measure. According to the 2014 Action Plan, prevention involves:

...ensuring good formative conditions for children and youth, fighting poverty and working to ensure that everyone, regardless of their 
background, shall have a sense of belonging and be protected against discrimination.

(Norwegian Ministry of Justice and Public Security, 2014, p. 7)

A majority of the measures mentioned to prevent radicalisation are measures associated with the Norwegian welfare state, such as access to education, work, equal opportunities, poverty reduction, and integration. The underlying notion is that the ideals present in Norwegian society will also serve to prevent radicalisation. As such, counterterrorism has become a form of safeguarding vulnerable individuals with the means of the welfare state. Therefore, counterterrorism measures are no longer portrayed either as controversial or as trade-off between civil liberties and security. Rather, counterterrorism measures are seen as a means to protect society and vulnerable individuals.

Since the risk factors for radicalisation is considered to be the same as for other negative youth behaviours such as mental illness and crime, the suggested countermeasures are the same as for other negative youth behaviours:

The core of prevention of radicalisation and development of extremism is the same as for prevention of, among other things, school dropouts, drug problems and crime. This is about that we in all areas of society must strive to counteract the exclusion mechanisms in the everyday lives of all children and adolescents. We must work actively to prevent anyone from feeling that they are standing outside of the "great good community". We must try to help young people develop self-esteem and an identity related to being part of the community and not a marginalized and/or extremist environment.

(Levanger Municipality, 2015 p. 9)

The assumption that terrorism is caused by vulnerability and outsiderness implies that the local community is responsible for recognising and helping potential radicalised individuals.

In Norway, counterterrorism has traditionally been seen as the responsibility for the Police and the Norwegian Security Police (PST), although the Ministry of the Defence and the Ministry of Foreign Affairs have also historically had counterterrorism on their political agendas. Consequently, up to 2010, counterterrorism had mainly been considered a national and centralised responsibility. Thus, when the 2010 Action Plan introduced a decentralisation of Norwegian counterterrorism responsibility, this was a new trajectory in Norwegian counterterrorism. The majority of the measures suggested in this document were measures that had to be executed on the municipality level. The numerous municipality guidelines published after this are a direct result of this reorganisation and downscaling of counterterrorism responsibility. According to Roger Berg of the national Police Security Service, "the beginning of a radicalisation process is not a direct Police 
Security Service matter but first and foremost a social responsibility" (Cited in Birkenes Municipality, 2018. p. 7).

When counterterrorism is turned into a social responsibility, it is no longer the state that is responsible for counterterrorism. On the contrary, counterterrorism is embedded into the everyday practices on the local level. In fact, many of the guidelines published on the municipality level not only target local community organisations but also individuals close to a potentially radicalised person, as illustrated by a quote in a report by Bømlo, Fitjar, and Stord Municipalities (2016, p. 8):

Are you an individual who is concerned about a neighbour, colleague, or another citizen you should do the following: Take the concern seriously! Think about what you are upset about and take responsibility for your unrest! ${ }^{1}$

Such statements point directly to the individual citizen, suggesting that everyone is responsible for countering terrorism. The joint responsibility of counterterrorism is constantly repeated in the guidelines for preventing radicalisation. The Norwegian Prime Minister, Erna Solberg, claims: "It is the responsibility of each of us to prevent radicalisation and violent extremism" (cited in Emergency Preparedness Council, 2018). It is worth noting that this is a welfare state argument; everyone has to take care of each other to achieve security. The idea is that by imposing a sense of community where everyone acts as responsible citizens, terrorism will be prevented.

The appropriate tool to be utilised when concerned for a potential "radicalised person, according to the Action Plan, for how to prevent radicalisation and violent extremism in 2010 is dialogue:

We must do more to prevent undesirable behaviour before it is too late and we must do so in a broad perspective. We must resolve conflicts, rather than aggravate and create new ones and we must choose dialogue rather than creating a divide between individuals and groups. It is through increased democratic participation that we can drive back those who wish to use violence to achieve their political goals...We will combat such views with words. Racist and discriminating views should be met on a broad front. This is our joint social responsibility.

(Ministry of Justice and Public Security, 2010, p. 5)

In fact, the national guide for the prevention of radicalisation and violent extremism from 2015 (Ministry of Justice and Public Security, 2015) and the majority of the municipalities' action plans offer concrete descriptions on how to create dialogue with potential radicalised individuals. Norwegian authorities have always highlighted "dialogue" as a legitimate counterterrorism means. Consequently, the use of dialogue as a counterterrorism measure is in line with the historical Norwegian perspective on 
counterterrorism. Nevertheless, the radicalisation approach diverges from the traditional Norwegian perspective on terrorism in that dialogue from this approach is not a means to negotiate or reach political consensus but a means to build robustness in individuals and to make potential terrorists refrain from extreme ideas. Thus, dialogue can be used not to achieve political consensus but as a therapeutic means. As such, radicalised views are not rational political opinions, but something that can be stopped if only individuals are integrated into harmonious local communities.

\section{Discussion}

Norwegian authorities have for several decades conceptualised terrorism as a form of political communication and claimed that terrorism should be prevented by focusing on root causes and social justice. The current radicalisation approach thus diverges from previous approaches on terrorism in three different ways. First, the radicalisation approach focuses on individual vulnerability factors. Second, it regards counterterrorism as a process of attitude change. Third, counterterrorism measures in the radicalisation approach are turned into something positive that are needed to build a safe and democratic society.

The first way the radicalisation approach differs from previous Norwegian discourses is in the way that explanatory factors for the causes of terrorism are predominantly ascribed to the individual level. In the concept of radicalisation lays a promise that there is a certain pathway that individuals are on in the process of becoming a terrorist that can be disrupted if only the right measures are in place. Psychological distress of individuals is described as the causes of terrorism, pointing at the individual as the locus of change. Consequently, the radicalisation approach downplays the political aspects of terrorism and focus on explanations and solutions on the micro level instead of national or international levels. The radicalisation approach removes the emphasis on terrorists as rational political individuals, seeing potential terrorists as vulnerable individuals that need to be safeguarded by the local environment. From this perspective, individuals and actors on the local level become a form of "first line defence" where counterterrorism is everyone's responsibility (Larsson, 2017; Petersen and Tjale, 2013). This has implication for the governance of security: it suggests not only that terrorism can be prevented if we achieve a just society; it is also made clear that counterterrorism is a societal responsibility and a social practice that everyone has to participate in.

Consequently, the radicalisation approach offers solutions to the problem of terrorism that can be implemented on a local level. The idea is that if the structures and measures already in place in Norway are utilised, these will also prevent terrorism. Thus, the concept of radicalisation, as it is deployed in the Norwegian approach, conceals the diversity of explanatory factors and proposes that individuals who become terrorists share a common set of 
characteristics or vulnerability (Awan et al., 2011; Hoskins and O'Loughlin, 2009; Neumann, 2013; Sedgwick, 2010). Because terrorism is seen as the result of socio-psychological vulnerability factors, measures associated with the proper functioning of the Norwegian welfare state will also prevent terrorism. Research conducted in Norwegian municipalities has showed that those officials working with radicalisation tended to have similar view on possible signs of radicalisation. They viewed the causes of radicalisation as similar to crime, drug abuse, and violent behaviour (Lid et al. 2016; Sandrup et al.2018). Consequently, terrorism is no longer seen as a product of a political struggle, but as a product of growing up or living in an environment characterised by negative risk factors.

The second way the radicalisation approach diverges from previous Norwegian terrorism approaches is in the way that it stretches the phenomena of terrorism and counterterrorism into the mind and the attitudes of individuals. In the radicalisation approach, emphasis is placed on having the right attitudes. However, attitudes in the radicalisation approach are not seen as a result of political process or social injustice. Attitudinal change in the radicalisation approach is caused by individuals vulnerable to extreme worldviews. Counterterrorism has become a question of having the right attitudes and a form of mental robustness. As a consequence, local actors such as teachers, social workers, and youth workers are turned into security actors representing the state and looking for alarming signs of attitude change (Mattsson, 2019). This is a dangerous trajectory for a democratic society because most individuals with a radicalised worldview will not use violence as a tool. Additionally, what is considered radical in one era might be considered mainstream in another. One might note that the Norwegian traditional conceptualisation of terrorism, focused on terrorists as fighting for a legitimate political issue, is no longer valid under the radicalisation approach.

The third way that the radicalisation approach diverges from the historical substantiation of terrorism is in the framing of counterterrorism measures. Historically in Norway, there has always been scepticism of implementing counterterrorism measures. The counterterrorism measures implemented in the aftermath of $9 / 11$ were debated and criticised, especially the War on Terrorism, surveillance, fortification of civil society, and new terrorism legislation. The argument for implementing these measures was that in order to achieve security, civil liberties had to be sacrificed. The measures proposed in the radicalisation approach have not met the same criticism. Many of the local actors who carry out local counterterrorism policy have welcomed the increased focus on communities and civil society in counterterrorism (Sjøen and Jore, 2019). Accordingly, government-centric efforts regarding counterterrorism lack credibility, and, consequently, communities and local actors are better situated to have the knowledge on what measures are required at a local level to prevent radicalisation (Dalgaard-Nielsen, 2016). However, after scrutinising the national and local documentary evidence in this study, one striking observation is how similar the plans are. The local action plans 
do not describe any profound understanding of, or reflection on, local needs nor adaptation to the presence of potential individuals in the local community in focus. Thus, even though numerous local action plans exist, these are not locally adapted strategies but rather formal procedures.

The storyline embedded in the radicalisation approach is that terrorism is a pressing problem to Norwegian security and that the whole of society needs to assist the state to prevent the ubiquitous threat of terrorism from materialising. Since the counterterrorism measures proposed in the radicalisation approach are dialogue, equality, social justice, and building robust citizens who thrive in their local community, counterterrorism measures are in line with what Norwegian citizens consider the role of the welfare state. As such, counterterrorism in the radicalisation approach becomes a form of caregiving and safeguarding of vulnerable individuals. Consequently, while counterterrorism measures previously were portrayed as threats to civil liberties, the radicalisation approach's preventative efforts are instead considered a key element of ensuring fundamental values such as democracy, human rights, and security. Thus, counterterrorism measures are no longer described as a negative that have to be weighed against civil liberties to gain security from terrorism. Quite the opposite, in fact, counterterrorism in the form of preventing radicalisation has now become a means to achieve civil liberties, human rights, and democracy (Norwegian Ministry of Justice and Public Security, 2014). Since counterterrorism measures are generally described as measures consistent with the welfare state, counterterrorism is not presented as a required trade-off but as a positive engagement that will create robust individuals, safe local communities, and an equal and inclusive society. However, even though most Norwegian citizens may believe that social justice, inclusion, and building robust individuals are ideal goals in a welfare state, there seems to be little discussion in Norway of whether these measures are effective counterterrorism measures or not. Thus, the positive framing of such measures also entails that debates regarding the negative side-effects of counterterrorism measures are curtailed in the Norwegian approach. This idea of safeguarding vulnerable individuals is probably an explanatory factor for why the radicalisation approach has been subject to such little criticism. The notion of safeguarding vulnerable individuals is in line with the Norwegian model and the welfare state that ascribes to local actors such as teachers, social workers, and the local police the role of preventing crime and social problems in the local environment. Nevertheless, the safeguarding lens takes the focus away from the fact that a wider array of society has become security agents and that such a regime might contribute to normalising distrust.

\section{Conclusions}

Norwegian authorities have for several decades conceptualised terrorism as a form of political communication and claimed that terrorism should be prevented by focusing on root causes and social justice. The focus on root 
causes, social harmony, and equality that features prominently in the Norwegian radicalisation approach makes it a counterterrorism policy that fits the Norwegian view on what terrorism is and how it should be prevented. However, the radicalisation approach represents a substantial change in Norwegian counterterrorism policy by describing terrorism as a result of individuals vulnerable to attitude change caused by social-psychological factors. Thus, political aspects and factors on the macro level are downplayed. Perhaps the most radical change in the Norwegian counterterrorism policies, though, is that counterterrorism measures no longer are seen as controversial or negative. The radicalisation approach transforms counterterrorism into something positive that is needed in order to build a safe and democratic society; counterterrorism is in the radicalisation approach described as a part of the public good and the welfare of the members of society. The measures build on the already existing structures of the welfare state, and are expected to develop a form of resilience in in the face of extreme attitudes.

The focus on radicalisation in counterterrorism is not a trend unique for Norway or the Nordic countries; this is an international trend seen in policy responses worldwide (Kundnani and Hayes, 2018). The radicalisation approach is an attempt to counter terrorism within a democratic frame with legitimate means. However, the so-called democratic approaches to counterterrorism can also have negative consequences. In many other countries, radicalisation and resilience policies have been criticised for being a part of a neoliberal tendency where the state redirects responsibility to the local level in order to save costs (see, e.g., Chandler and Reid, 2016). In Norway, with a well-developed and rich welfare state, this neoliberal argument has not been present. The radicalisation approach and its accompanying counterterrorism perspective offer a solution to terrorism that fits the values of the welfare state that Norwegian society is based on. Additionally, since counterterrorism is portrayed as a form or caregiving and safeguarding of vulnerable individuals, this approach is framed as a positive element and in line with how local actors see their role in the Norwegian welfare state. This is probably why this approach to counterterrorism has faced so little criticism in Norway compared to many other countries. Since radicalisation is primarily understood as a result of socio-economic conditions and individual vulnerability, it makes sense that local actors and individuals close to a potential radicalised person are considered the ones who have the possibility to discover early warning signs and therefore prevent radicalisation. Moreover, the idea of conflating the welfare state with security has a long-standing tradition in Norway. In Norway, there is a tradition of solving risk problems at the municipality level. Thus, the devolution of counterterrorism responsibility fits, in some respects, the Norwegian model on how to manage risks in general and security threats in particular. A closer look, however, reveals that although the radicalisation approach may, on a superficial level, look like an extension of former counterterrorism policies, in practice the 
approach is a radical change in Norwegian counterterrorism policies that might contribute to increased distrust and alienation. There is every reason to question, therefore, whether it is time for Norwegian authorities to reflect upon the current policy trajectory and whether changes are needed.

\section{Notes}

1 All translations from Norwegian into English have been done by the author.

2 Adapted from: Lillesand Municipality (2016), p. 10.

3 Adapted from Ministry of Justice and Public Security (2014).

\section{References}

Aly, A. (2013). The Policy Response to Home-Grown Terrorism: Reconceptualising Prevent and Resilience as Collective Resistance. Journal of Policing, Intelligence and Counter Terrorism 8 (1), 2-18.

Awan A., Hoskins A, and O'Loughlin B, (2011). Radicalisation and Media: Connectivity and Terrorism in the New Media Ecology. Abingdon: Routledge.

Birkenes Municipality. (2018). Veileder Forebygging av radikalisering og voldelig ekstremisme. Fra bekymring til handling [Only in Norwegian]. Available at: www. plattform.no/media/1075/birkenes-veileder-om-forebygging-av-radikaliseringog-voldelig-ekstremisme.pdf. Accessed 2 March 2019.

Borum, R. (2011). Radicalisation into Violent Extremism I: A Review of Social Science Theories. Journal of Strategic Security 4 (4), 7-36.

Burgess, P. \& Jore, S.H. (2008). The Influence of Globalization on Societal Security: The International setting. PRIO Briefing paper, 1/2008. Available at: www.prio. no/sptrans/-959280262/The $\% 20$ Influence $\% 20$ of $\% 20$ Globalization $\% 20$ on $\% 20$ Societal $\% 20$ Security $\% 20-\% 20$ The $\% 20$ International $\% 20$ Setting.pdf. Accessed 2 November 2010.

Chandler, D. and J. D. M. Reid. (2016). The Neoliberal Subject: Resilience, Adaptation and Vulnerability. London: Rowman \& Littlefield International.

Crelinsten, R. D. (2009). Counterterrorism. Cambridge: Polity.

Crone M. (2016). Radicalization revisited: Violence, politics and the skills of the body. International Affairs 92(3), 587-604.

Dalgaard-Nielsen, A. (2016). Countering violent extremism with governance networks. Perspectives on Terrorism 10(6), 135-139.

Emergency Preparedness Council. (2018). Suggested Actions for Prevention of Radicalisation and Violent Extremism in the University and College Sector. Council on Civil Protection and Preparedness in the Knowledge Sector. Available at: www.uis.no/getfile. $\mathrm{php} / 13491727 / \mathrm{SEROS} /$ Beredskapsr $\% \mathrm{C} 3 \%$ A5det/Tiltaksliste $\% 20$ Beredskapsr $\%$ C3\%A5det\%20ENGLISH\%20version\%281\%29.pdf. Accessed 2 March 2019.

Horgan, J. (2008). From Profiles to Pathways and Roots to Routes: Perspectives from Psychology on Radicalisation into Terrorism. The Annals of the American Academy of Political and Social Science 618 (1), 80-94.

Hoskins A. and O'Loughlin B. (2009). Pre-mediating guilt: Radicalisation and mediality in British news. Critical Studies on Terrorism 2(1), 81-93.

Jackson, R., Lee J., Jeroen G. and M. Breen-Smyth (2011). Terrorism: A Critical Introduction. London: Macmillan International Higher Education. 
Jore, S.H. (2012). Counterterrorism as Risk Management Strategies. University of Stavanger, PhD Thesis UiS no. 178. Faculty of Science and Technology, University of Stavanger.

Jore, S. H. (2016). Norwegian Media Substantiation of Counterterrorism Measures. Journal of Risk Research 19 (1), 101-118.

Jore, S. H., \& Njå, O. (2008). "Protection from Half-Criminal Windows Breakers to Mass Murderers with Nuclear Weapons": Changes in the Norwegian authorities' discourses on the terrorism threat. In S. Martorell, C. Guedes Soares \& J. Barnett (Eds.), Safety, Reliability and Risk Analysis. Theory, Methods and Applications (pp. 3077-3084). London: Taylor \& Francis Group.

Jore, S. H., \& Njå, O. (2009). Terrorism Risk as a Change Stimulus to the Norwegian Society. In R. Briš, C. Guedes Soares \& S. Martorell (Eds.), Reliability, Risk and Safety. Theory and Applications (pp. 2265-2274). London: Taylor \& Francis Group.

Kolås Å. (2017). How critical is the event? Multicultural Norway after 22 July 2011. Social Identities 23(5), 518-53.

Kundnani, A., \& Hayes, B. (2018). The Globalisation of Countering Violent Extremism Policies: Undermining Human Rights, Instrumentalising Civil Society. Amsterdam: Transnational Institute.

Larsen, A. G. (2018). Threatening Criminals and Marginalized Individuals: Frames and News Conventions in Reporting of Radicalisation and Violent Extremism. Media, War \& Conflict. doi:10.1177/1750635218769331.

Larsson, S. (2017). A First Line of Defence? Vigilant Surveillance, Participatory Policing and the Reporting of 'Suspicious' Activity. Surveillance \& Society 15 (1), 94-107.

Lid, S., Søholt, S. and Hansen, S.J. m.fl. (2016). Forebygging av voldelig ekstremismeHva er kommunenes rolle? By- og regionforskningsinstituttet NIBR, Høgskolen i Oslo og Akershus

Levanger Municipality. (2015). Veileder Hvordan forebygge radikalisering og håndtere voldelig ekstremisme i Nord-Trøndelag [Only in Norwegian]. Available at www. levanger.kommune.no/Global/dokumenter/radkalisering_voldelig_ekstremisme_ forebygging_231015.pdf. Accessed 2 March 2019.

Lillesand Municipality. (2016). Hvordan håndtere bekymring for radikalisering og voldelig ekstremisme [Only in Norwegian]. Available at: www.lillesand. kommune.no/Global/Tjenestebeskrivelser/Helse $\% 20$ og $\% 20$ omsorg/veileder $\% 20$ radikalisering.pdf. Accessed 2 March 2019.

Mattsson, C. (2019). Policing Violent Extremism: How the Global War on Terror Meandered into Local Municipal Policies in Sweden. Sage Open 9(1), doi:10.1177/2158244019837462.

Ministry of Justice. (1993) no. 3: Criminal Legislation for Combating Terrorism.

Ministry of Justice and Public Security. (2010). Action Plan against Radicalisation and Violent Extremism. Available at: www.counterextremism.org/resources/ details/goto_url/670/8796. Accessed 2 March 2019.

Ministry of Justice and Public Security. (2014). Action Plan against Radicalisation and Violent Extremism. Available at: www.regjeringen.no/contentassets/6d84d 5d6c6df47b38f5e2b989347fc49/action-plan-against-radicalisation-and-violentextremism_2014.pdf. Accessed 2 March 2019.

Ministry of Justice and Public Security (2015). National Guide for the Prevention of Radicalisation and Violent Extremism [Only in Norwegian]. Available at: www.regjeringen.no/no/sub/radikalisering/veileder/veileder-som-pdf/id2405821/. Accessed 2 March 2019. 
Neumann P. (2013.) The trouble with radicalization. International Affairs 89(4), 873-893.

Petersen, K. L., and Tjalve, V. S. (2013). (Neo) Republican Security Governance? US Homeland Security and the Politics of "Shared Responsibility". International Political Sociology 7(1), 1-18.

Sageman, M. (2014). The Stagnation in Terrorism Research. Terrorism and Political Violence 26 (4), 565-580.

Sandrup, T., Weiss, N., Skiple, A., \& Hofoss, E. (2018). Radikalisering-En studie av mobilisering, forebygging og rehabilitering [Only in Norwegian]. Available at: https://publications.ffi.no/bitstream/handle/20.500.12242/2225/01591.pdf?sequence=1. Accessed 2 March 2019.

Sivenbring, J. and R. A. Malmros (2019). Mixing Logics. Multiagency Approaches for Countering Violent Extremism. The Segerstedt Institute of Gothenburg University. Available at: https://segerstedtinstitutet.gu.se/digitalAssets/1760/1760437_ mixing-logics_digital.pdf. Accessed 2 January 2020.

Sedgwick, M. (2010). The Concept of Radicalisation as a Source of Confusion. Terrorism and Political Violence 22 (4), 479-494.

Sjøen, M. M., \& Jore, S. H. (2019). Preventing Extremism through Education: Exploring Impacts and Implications of Counter-Radicalisation Efforts. Journal of Beliefs \& Values 40, 1-15.

Tromsø Municipality. (2018). Handlingsveileder ved bekymring for Radikalisering $O g$ Voldelig Ekstremisme [Only in Norwegian] Available at: Tromsø.kommune.no/ veileder. Accessed 2 March 2019.

\section{List of national guidelines and action plans for preventing radicalisation}

- Ministry of Justice and Public Security (2010). Action Plan against Radicalisation and Violent Extremism. Available at: https://www.counterextremism.org/ resources/details/goto_url/670/8796. Accessed 2 March 2019.

- Ministry of Justice and Public Security (2014). Action Plan against Radicalisation and Violent Extremism. Available at: https://www.regjeringen. no/contentassets/6d84d5d6c6df47b38f5e2b989347fc49/action-plan-againstradicalisation-and-violent-extremism_2014.pdf Accessed 2 March 2019.

- Ministry of Justice and Public Security (2015). National guide for the prevention of radicalisation and violent extremism. \{Only in Norwegian\}. Available at: https://www.regjeringen.no/no/sub/radikalisering/veileder/veileder-sompdf/id2405821/ Accessed 2 March 2019.

- Emergency Preparedness Council (2018).Suggested actions for prevention of radicalisation and violent extremism in the university and college sector. Council on Civil Protection and Preparedness in the Knowledge Sector. Available at: https://www.uis.no/getfile.php/13491727/SEROS/Beredskapsr\%C3\%A5det/ Tiltaksliste $\% 20$ Beredskapsr\%C3\%A5det $\% 20$ ENGLISH $\% 20$ version $\% 281 \% 29$. pdf Accessed 2 March 2019.

\section{List of municipalities studied}

- Oslo Municipality

- Kristiansand Municipality

- Time Municipality 


\section{Sissel H. Jore}

- Lillesand Municipality

- Birkenes Municipality

- Tromsø Municipality

- Lenvik Municipality

- Hamar Municipality

- Bergen Municipality

- Stavanger Municipality

- Gjøvik Municipality

- $\quad$ Ålesund Municipality

- Salto Bærum Municipality

- Elverum Municipality

- Sandefjord Municipality

- Gjesdal Municipality

- Larvik Municipality

- Lindesnes Municipality

- Skien Municipality

- $\quad$ Øygarden Municipality

- Lyngdal Municipality

- Stjørdal Municipality

- Gran and Lunner Municipalities

- Øvre Eiker Municipality

- Berum Municipality

- Horten Municipality

- Lesja, Dovre, Sel, Vågå, and Lom Municipalities

- Trondheim Municipality

- Vestre Toten Municipality

- Søgne and Sogndalen Municipalities

- Risør Municipality

- Marker og Rømskog Municipalities

- Lillehammer Municipality

- Frosta Municipality 